DOI 10.32370/IA_2019_01_13

\title{
The State of Forming Moral Culture in Future Foreign Languages Teacher
}

\author{
Petliaieva Vera \\ ORCID https://orcid.org/0000-0003-2752-2354 \\ Mykolaiv V.O. Sukhomlynskyi National University (Ukraine)
}

\begin{abstract}
The article deals with the problem of moral culture education among students at higher pedagogical educational institutions in the system of training a foreign language teacher. In modern society, when the problems of cultural and spiritual revival of Ukraine are exacerbated, the formation of moral culture in the future teachers should be seen as the most important prerequisite for forming Ukrainian statehood. The modern researches and publications on the issue of education of the moral culture in the future teacher of foreign languages are analyzed in the article. The criteria of forming moral culture in future teacher of foreign languages are defined. In accordance with the criteria of forming moral culture in future foreign languages teacher the levels are specified. The author presents the results of forming moral culture in future foreign language teachers, conducted on the basis of Dragomanov National Pedagogical University (Kyiv) and Mykolaiv Sukhomlynskyi National University.
\end{abstract}

Key words: future foreign language teachers, moral culture, university.

Постановка проблеми у загальному вигляді. Інтегрування України у загальноєвропейський простір, розвиток ії демократичної державності та трансформація усіх сфер життя потребують значних змін у національній системі вищої освіти, підвищення іï якості, оновлення змісту, добору ефективних форм, засобів і методів навчання. Актуалізація проблеми формування моральної культури майбутніх учителів на сучасному етапі розвитку суспільства викликана по-перше, інтеграцією України до європейського освітнього простору, а по-друге, становленням української державності.

Дослідження свідчать, що моральна культура більш ніж будь-яке інше структурне утворення внутрішнього світу людини визначає соціальну стійкість системи iii взаємин із суспільством, 3 іншими людьми, ефективно впливає на формування свідомості, самосвідомості та професійних якостей. Моральна культура особистості пронизує всі сфери діяльності людини, в тому числі й навчання. Тому формування цього якісного утворення у студентів педагогічних вищих навчальних закладів $\epsilon$ важливим і необхідним процесом у сучасній соціально-педагогічній ситуації $[3 ; 4 ; 5 ; 6$; $9 ; 11 ; 12 ; 13]$. 
Постановка проблеми обумовила мету статті - висвітлити результати діагностування сформованості моральної культури майбутнього вчителя іноземних мов.

Аналіз останніх досліджень і публікацій. В сучасних умовах розвитку суспільства науково-теоретичні засади формування особистості майбутнього вчителя, його загальної i, зокрема, моральної культури розроблялися у працях К. Байші, Л. Бурдейної, Л. Вовк, І. Грязнова, В. Діуліної, І. Зязюна, О. Кузнєцової, В. Лозового, Г. Полякової, Л. Петько, О. Пометун, А. Ремньової, О. Савченко, О. Сухомлинської.

Окремі аспекти виховання моральної культури на заняттях з іноземної мови розглянуті у дослідженнях зарубіжних методистів та лінгвістів (А. Amer, G. Auernheimer, M. Carrier, W. Gates, G. Grecia, F. Janshof, R. Kern, G. Neuner, R. Oxford, M. Schwartz, A. Virlacher та ін.).

Виклад основного матеріалу. Домінантні імперативи сучасної гуманістичної тріади «людина-освіта-культура» відображені в мовній політиці держави, прийнятті нею вектору полікультурної й освітянської політики, зорієнтованої на збереження, розвиток й активне використання державної, рідної та іноземних мов, формування здатності людини до крос-культурного діалогу [10, с. 170; 11].

Як зазначає В. Андрущенко у своїх наукових працях «Любити дитину і людей, бути патріотом власної держави і громадянином світу, морально і соціально високою особистістю, носієм гуманістичних цінностей, авторитетом у своїй предметній галузі і соціальному досвіді тощо, були і залишаються ознаками людини, яку в усі часи і всі народи називали «вчителем»»» [1, с. 9].

Розкриття сутності поняття «моральна культура» потребує аналізу дефініцій «культура» та «мораль».

Педагогічний погляд на культуру та мораль прослідковується у визначенні, наведеному в «Українсько-англійському словнику навчально-педагогічних понять i термінів». Л. Вовк трактує поняття «базова культура особистості» як цілісність, що включає в себе оптимальну наявність властивостей, якостей, орієнтацій особистості, що дозволяють розвиватися в гармонії із суспільною культурою тобто вносити в іiі розвиток посильний внесок. Реалізація змісту базової культури спрямована на формування особистості, яка поєднує в собі світоглядну культуру, громадянськість та 
творчу індивідуальність. Основою базової культури є загальнолюдські цінності. «Мораль» (лат. moralis - моральний,mores - звичаї) трактується як одна із форм суспільної свідомості; система поглядів і уявлень, норм і оцінок, що регулюють поведінку дітей [2, с. 58].

Вирішення основних завдань дослідження, окрім вивчення філософської, психолого-педагогічної літератури а також узагальнення освітньої та виховної специфіки педагогічних вузів, передбачало проведення експериментальної діагностики наявного рівня моральної культури майбутніх учителів іноземної мови.

Протягом 2015-2016 н.р. було опитано 311 студентів другого курсу спеціальності «іноземна філологія», з них - 143 в НПУ імені М.П.Драгоманова і 168 у Миколаївському університеті імені В.О.Сухомлинського.

Рівень моральної культури у майбутніх учителів іноземних мов визначався за трьома основними критеріями: 1)мотиваційно-ціннісний (здатність до співчуття, співпереживання; міцність моральних переконань; наявність оціночних і рефлексивних умінь; адекватна самооцінка; ставлення до моральної культури як до цінності, любов до неї, прагнення до дотримання моральних принципів, норм та правил; вміння оцінити вплив зарубіжної культури на українську культуру, прагнення знайомити дітей 3 моральними цінностями народів, які розмовляють англійською мовою. - визначався за допомогою спостережень, бесід, анкетування), 2) когнітивний (повнота уявлень про гуманістичну педагогічну культуру і якості, необхідні вчителю; усвідомленість, глибина і системність етичних знань; інтерес до моральних цінностей української, зарубіжної та світової культури, потреба розширювати свій кругозір в області етики, активна позиція у придбанні етичних знань - методом експертних оцінок, спостережень, тестування та анкетування), 3) діяльнісний (сформованість моральних звичок; вміння робити моральний вибір у новій ситуації, керуючись високоморальними мотивами, здатність до морального i професійного самовдосконалення;вміння транслювати духовні цінності рідної та зарубіжної культури - метод експертних оцінок, спостереження, аналіз творчих робіт).

У відповідності з цими критеріями були складені узагальнені характеристики трьох рівнів сформованості моральної культури: 
Високий рівень. Студенти характеризуються стійкою спрямованістю на моральне самовдосконалення, що корелює з досить стійкою професійною спрямованістю. Достатній piвень. Студенти характеризуються малостійкою спрямованістю на моральне самовдосконалення, що корелює з професійною спрямованістю різного ступеня стійкості. Початковий рівень. Спрямованість на моральне самовдосконалення відсутня або виражена слабо. Студенти націлені на отримання диплома про вищу освіту і не готують себе до педагогічної діяльності.

Діагностика сформованості моральної культури у майбутніх учителів іноземних мов (студентів 1-го курсу) проводилася на початку навчального року. 3 цією метою ми пропонували студентам заповнити анкету, зміст якої представлено нижче.

\section{Анкета}

1. Що таке моральна культура особистості?...

2. На які цінності Ви орієнтуєтесь в житті?...

3. Які вимоги ставить перед Вами майбутня професія?...

4. На скільки моральна поведінка обмежує Вашу свободу?...

5. Чим Ви керувалися при виборі Вашої майбутньої професії?...

6. Звідки Ви черпаєте приклади моральної поведінки:

а) література...

б) засоби масової інформації...

в) освітньо-виховне середовище університету...

г) Ваш варіант...

Своєю чергою, змістовна характеристика кожного з показників оцінювалися 2, 3, 4 та 5 балами відповідно до шкали: 2 бали - початковий рівень (нерозуміння сутності найважливіших сторін моральної культури або негативне ставлення до необхідності їі формування майбутньому вчителю); 3 бали - достатній рівень: адекватне розуміння сутності відповідних ознак моральної культури, позитивне ставлення та бажання (хоча і нестійке) до необхідності їі формування майбутньому вчителю; 4 бали - високий рівень, глибоке розуміння сутності провідних ознак тих або інших сторін моральної культури, стійке бажання до самостійного її вдосконалення.

Таблиця 1 містить узагальнені результати рівнів сформованості моральної культури майбутніх учителів іноземних мов. 
Аналіз відповідей анкет дозволив нам визначити рівні сформованості моральної

Таблиия 1

Узагальнені результати рівнів сформованості моральної культури майбутніх учителів іноземних мов на початку експерименту (в абсолютних числах, \%)

\begin{tabular}{|l|c|c|c|c|c|c|}
\hline \multirow{3}{*}{ Групи } & \multicolumn{6}{|c|}{ Рівні } \\
\cline { 2 - 8 } & \multicolumn{2}{|c|}{ Високий } & \multicolumn{2}{c|}{ Достатній } & \multicolumn{2}{|c|}{ Початковий } \\
\cline { 2 - 8 } & К-сть осіб & $\%$ & К-сть осіб & $\%$ & К-сть осіб & $\%$ \\
\hline Контрольна & 13 & 8,4 & 51 & 33,1 & 90 & 58,5 \\
\hline Експериментальна & 12 & 7,6 & 53 & 33,8 & 92 & 58,6 \\
\hline
\end{tabular}

культури майбутніх учителів іноземних мов. Таким чином, можемо бачити, що більше половини опитаних студентів - майбутніх учителів іноземної мови мають початковий рівень моральної культури у контрольній та експериментальній групах; достатній рівень сформованості моральної культури мають $33,1 \%$ студентів контрольної групи та 33,8 \% експериментальної групи; високий рівень моральної культури виявили $-8,4 \%$ студентів контрольної групи та 7,6 \% експериментальної, що, на жаль, не може задовольняти потреби сучасної української школи та суспільства.

Висновки. Отже, на підставі викладеного вище можемо стверджувати, що більше половини опитаних студентів - майбутніх учителів іноземної мови мають початковий рівень моральної культури, що не відповідає потребам сучасної української школи, а система професійної підготовки майбутніх учителів потребує вдосконалення.

\section{References}

1. Andrushchenko V.P. Rozdumy pro vchytelia [Thoughts about the teacher]. Vyshcha osvita Ukrainy. 2011. No. 2. P. 6-12.

2. Vovk L.P. Ukrainsko-anhliiskyi slovnyk navchalno-pedaphohichnykh poniat ta terminiv: metod. pos. [Ukrainian-English dictionary of educational and pedagogical concepts and terms] / ukl. L. Vovk [ta in.]. Kyiv: Ukrainskyi tsentr dukhovnoi kultury, 2006. 154 p.

3. Komarovska O.A. Teatr $i$ shkola: vykhovuiut odnodumtsi [Theater and school]. Knyha dlia vchytelia ta batkiv. Nizhyn: TOV «Vyd-vo «Aspekt-Polihraf», 2006. 
4. Petko L.V. Vykhovnyi potentsial metodu sytuatsiinoho analizu ( Case study» method) u formuvanni profesiino oriientovanoho inshomovnoho navchalnoho seredovyshcha $v$ umovakh universytetu [Educational potential of the «Case study» method for the forming of the professionally oriented foreign language teaching environment in the conditions of university]. Naukovyi chasopys NPU imeni M.D.Drahomanova. Seriia 17. Teoriia i praktyka navchannia ta vykhovannia : zb. nauk. pr. Kyiv: Vyd-vo NPU imeni M.P.Drahomanova, 2015. Issue 27. P. 133-140.

5. Petko L.V. Realizatsiia moralno-suspilnoi problematyky u formuvanni profesiino oriientovanoho inshomovnoho navchalnoho seredovyshcha $v$ umovakh universytetu [Implementation of the moral and social problems in formation of professionally oriented foreign language learning environment in conditions of university]. Naukovyi chasopys NPU imeni M.D.Drahomanova. Seriia 5. Pedahohichni nauky: realii ta perspektyvy: zb. nauk. pr. Kyiv: Vyd-vo NPU imeni M.P.Drahomanova, 2016. Issue 55. P. 166-173.

6. Pet'ko L.V. Formuvannja duhovnyh cinnostej studentskoi molodi shljahom stvorennja profesijno sprjamovanogo inshomovnogo navchal'nogo seredovyshha $v$ umovah universytetu (na prykladi vyvchennja anglijs'koju movoju novely O'Genri «Ostannij lystok») [The formation of the spiritual values of students' by creating professionally oriented foreign language learning environment in the conditions of the university (for example of studying a short story "The Last Leaf" by O. Henry)] / Problemy osvity: zb. nauk.-metod.prac. Kyiv, 2014. Vol. 79. P. 302-307.

7. Petko L.V. Formuvannya profesiyno orientovanogo inshomovnogo navchalnogo seredovishcha $v$ umovah universitetu shlyahom rozglyadu moralnih orientiriv studentiv [Formation of professionally oriented foreign language teaching environment in terms of university by considering of students' moral orienting points]. Pedagogichniy almanah: zb. nauk. pr. ; redkol. V.V.Kuzmenko ta in. Herson: KVNZ «Hersonska akademiya neperervnoyi osviti, 2016. Issue 29. P. 164-172.

8. Turchynova H.V. Biolohichne piznannia u kontynuumi osobystisnoi dynamiky studentiv [Biological knowledge in the continuum of personal dynamics of students] // Osobystist u prostori vykhovnykh innovatsii : materialy Vseukrainskoi nauk.-prakt. konf. Intu problem vykhovannia NAPN Ukrainy, 19 zhovtnia 2018 r. / [Za red. I. D. Bekha]. IvanoFrankivsk : NAIR, 2018. P. 371-376.

9. Turchinova G.V. Formuvannya profesiyno znachuschih yakostey maybutnogo vchitelya prirodnichih distsiplin [Forming professionally significant qualities in future teacher of Natural Sciences] / Kritichniy pidhid u vikladanni prirodnichih distsiplin: mater. Mizhnarodnoyi nauk.-metod. konf., 14 listopada 2018 roku / ukl. : O.P. Galay [ta in.]. Kiyiv: Vid-vo NPU imeni M.P. Dragomanova, 2018. P. 112-118.

10. Shykyrynska O.V. Rozvytok profesiinoi komunikatyvnoi kompetentnosti maibutnikh uchyteliv-filolohiv za dopomohoiu vykorystannia interaktyvnykh metodiv navchannia [Development of professional communicative competence of future teachers philologists through the use of interactive teaching methods] / SLOVIANSKA FILOLOHIIA: ISTORIIA, SOHODENNIA, PERSPEKTYVY: mat. vseukr. nauk.-prakt. konf. Uman: VPTs: "Vizavi", 2016. P. 170-178. 
11. Kovalynska I.V., Ternopilska V. I. A Survey of multicultural education in Ukraine: state approach // Science and practice: Collection of scientific articles. - Thorpe Bowker. Melbourne, Australia, 2016. P. 256-259.

12. Pet'ko Lyudmila. The "Case Study" Method as Means of Formation of a Professionally Oriented Foreign Language Teaching Environment in University Conditions. Intellectual Archive. 2015. Volume 4. No. 4 (July). Series "Education \& Pedagogy". Toronto: Shiny World Corp. PP. 48-65.

13. Pet'ko L.V. Formation of professionally oriented foreign language teaching environment in conditions of university and upbringing of moral and ethical values (on illustration of the phenomenon «honesty» and «lie»). Intellectual Archive. 2016. Volume 5. No. 1 (January). Toronto: Shiny World Corp., Canada. PP. 98-111.

\section{Translation of the Title, Abstract and References to the Author's Language}

\section{УДК 37.01:378}

Петлясва Віра. Діагностика стану сформованості моральної культури майбутнього вчителя іноземних мов.

У статті актуалізується проблема виховання моральної культури у студентів вищих педагогічних навчальних закладів в системі підготовки вчителя іноземної мови. Проаналізовано останні дослідження та публікації з проблеми виховання моральної культури майбутнього вчителя іноземних мов. Визначено критерії виховання моральної культури майбутнього вчителя іноземних мов. У відповідності 3 критеріями обгрунтовано рівні формування моральної культури майбутнього вчителя іноземних мов. Автором подано результати дослідження стану сформованості моральної культури майбутніх учителів іноземної мови, проведеного на базі Національного педагогічного університета імені М.П. Драгоманова та Миколаївського національного університету імені В.О. Сухомлинського протягом 2015-2016 н.р. згідно когнітивного, мотиваційноціннісного та діяльнісного критеріїв.

Ключові слова: майбутній учитель іноземних мов, моральна культура, університет.

Петляева Вера. Диагностика состояния сформированности нравственной культуры будущего учителя иностранных языков.

В статье актуализируется проблема воспитания нравственной культуры у студентов высших педагогических учебных заведений в системе подготовки учителя иностранного языка. Проанализированы последние исследования и публикации по проблеме воспитания нравственной культуры будущего учителя иностранных языков. Определены критерии воспитания нравственной культуры будущего учителя иностранных языков. В соответствии с критериями обоснованно уровне формирования нравственной культуры будущего учителя иностранных языков. Автором представлены результаты исследования состояния сформированности нравственной культуры будущих учителей иностранного языка, проведенного на базе Национального педагогического университета имени М.П. Драгоманова и Николаевского национального университета имени В.А. Сухомлинского течение 2015-2016 учебном году согласно когнитивного, мотивационно-ценностного и деятельностного критериев. 
Ключевые слова: будущий учитель иностранных языков, нравственная культура, университет.

\section{Лimepamypa}

1. Андрущенко В. П. Роздуми про вчителя. Вищза освіта України. 2011. № 2. С. $6-12$

2. Вовк Л. П. Українсько-англійський словник навчально-педагогічних понять та термінів: метод. пос. / укл. Л.Вовк [та ін.]. Київ: Український центр духовної культури, 2006. $154 \mathrm{c}$

3. Комаровська О. А. Театр і школа: виховують однодумці. Книга для вчителя та батьків. Ніжин: ТОВ «Вид-во «Аспект-Поліграф», 2006.

4. Петько Л. В. Виховний потенціал методу ситуаційного аналізу («Case study» method) у формуванні професійно орієнтованого іншомовного навчального середовища в умовах університету / Л.В.Петько // Науковий часопис НПУ імені М.Д.Драгоманова. Серія 17. Теорія і практика навчання та виховання: зб. наук. пр. ; за ред. академіка В.І.Бондаря. - Київ: Вид-во НПУ імені М.П.Драгоманова, 2015. - Вип. 27. - С. 133-140.

5. Петько Л. В. Реалізація морально-суспільної проблематики у формуванні професійно орієнтованого іншомовного навчального середовища в умовах університету. Науковий часопис НПУ імені М. П. Драгоманова. Серія 5. Педагогічні науки : реалії та перспективи: зб. наук. пр. Київ: Вид-во НПУ імені М. П. Драгоманова, 2016. Вип. 55. C. 166-173.

6. Петько Л. В. Формування духовних цінностей студентської молоді шляхом створення професійно спрямованого іншомовного навчального середовища в умовах університету (на прикладі вивчення англійською мовою новели О'Генрі «Останній листок»). Проблеми освіти: наук. зб. 2014. № 79. С. 302-307.

7. Петько Л. В. Формування професійно орієнтованого іншомовного навчального середовища в умовах університету шляхом розгляду моральних орієнтирів студентів. Педагогічний альманах: зб. наук. праць ; редкол. В. В.Кузьменко [та ін.]. Херсон: КВНЗ «Херсонська академія неперервної освіти», 2016. Вип. 29. С. 164-172.

8. Турчинова Г. В. Біологічне пізнання у континуумі особистісної динаміки студентів / Особистість у просторі виховних інновацій : матеріали Всеукраїнської науково-практичної конференції Ін-ту проблем виховання НАПН України, 19 жовтня 2018 р. / [за ред. І. Д. Беха, О. М. Докукіної, Р. В. Малиношевського]. Івано-Франківськ : HAIP, 2018. С. 371-376.

9. Турчинова Г. В. Формування професійно значущих якостей майбутнього вчителя природничих дисциплін // Критичний підхід у викладанні природничих дисциплін : матеріали Міжнародної науково-методичної конференції, 14 листопада 2018 року / укл. О. П. Галай [та ін.]. Київ: Вид-во НПУ імені М. П. Драгоманова, 2018. C. $112-118$.

10. Шикиринська О.В.Розвиток професійної комунікативної компетентності майбутніх учителів філологів за допомогою використання інтерактивних методів навчання / СЛОВЯНСЬКА ФІЛОЛОГІЯ: ІСТОРІЯ, СЬОГОДЕННЯ, ПЕРСПЕКТИВИ: матеріали всеукр. наук.-практ. конф. ; відп. за випуск Г.В. Осіпчук. Умань: ВПЦ: «Візаві», 2016. С. 170-178. 
11. Kovalynska I. V., Ternopilska V. I. A Survey of multicultural education in Ukraine: state approach // Science and practice: Collection of scientific articles. - Thorpe Bowker. Melbourne, Australia, 2016. P. 256-259.

12. Pet'ko Lyudmila. The "Case Study" Method as Means of Formation of a Professionally Oriented Foreign Language Teaching Environment in University Conditions. Intellectual Archive. 2015. Volume 4. No. 4 (July). Series "Education \& Pedagogy". Toronto: Shiny World Corp. PP. 48-65.

13. Pet'ko L.V. Formation of professionally oriented foreign language teaching environment in conditions of university and upbringing of moral and ethical values (on illustration of the phenomenon «honesty» and «lie»). Intellectual Archive. 2016. Volume 5. No. 1 (January). Toronto: Shiny World Corp., Canada. PP. 98-111. 